\title{
The Effect of The Head Master of Principal's Democratic Leadership Style on Motivation of Teacher Work in State of Madrasah Aliyah, Tapaktuan.
}

\author{
Muhsin \\ STAI Tapaktuan \\ muhsin_ma@yahoo.com
}

\begin{abstract}
Democratic leaders always try to stimulate their members to work cooperatively to achieve common goals. Democratic leadership places humans as the main and most important factor in each group / organization. The aim is To improve employee performance, efforts are needed to arouse employee motivation and other factors that influence it. this study is a quantitative approach is one of the efforts of scientific search (scientific inquiry) which is based on logical positivism philosophy about logic, truth, laws, and predictions (Watson in Danim). The results are the study show that there is an influence of the principal's democratic leadership style on teacher work motivation in the Tapaktuan Superior State Madrasah Aliyah.
\end{abstract}

Keywords : Democratic; Leadership; Motivation

\section{Introduction}

Democratic leaders always try to stimulate their members to work cooperatively to achieve common goals. Democratic leadership places humans as the main and most important factor in each group / organization. Democratic leadership in making decisions is very important for deliberation, which is realized at every level and within each unit.

High work motivation, among others, is characterized by a condition when a person has the opportunity to improve knowledge and skills, and has the opportunity to develop. Therefore, a person's work motivation can be seen from the opportunity concerned to develop themselves in order to improve their abilities and skills at work.

With regard to leadership, principals also meet effectively with teachers in conducive situations. In this case, the behavior of the principal must be able to encourage and motivate the work of the teachers by showing a sense of friendliness, closeness, and full consideration of the teacher, both as individuals and as a group. The principal's instrumental behavior is tasks that are oriented and directly clarified in the roles and tasks of the teacher, as individuals and as a group. Positive behavior of principals can encourage, direct, and motivate all school people to work together in realizing the vision, mission and goals of the school.

Researching the teacher as one of the implementers of educational activities in schools is very necessary. It is not uncommon to find teachers who lack passion in carrying out their duties, which results in a lack of successful goals. This is caused by various factors, one of which is the lack of motivation of the teacher's work.

One of the benchmarks in achieving school success is the mechanism or leadership style of the principal who is able to motivate the work of the teacher so that he can achieve the expected educational goals. The principal can influence the workings of the teachers, there are teachers who carry out their activities with enthusiasm and there are also some teachers who lack enthusiasm. Based on the results of research observations while carrying out Field Experience Practices (PPL) in the Superior Public School (MAN) of Tapaktuan, there appeared to be several problems such as teachers who lacked enthusiasm in planning such as making learning devices, there were teachers who were late and rarely entered at learning activities, and there are also teachers who do not use innovative learning methods, so it is not 
uncommon to find teachers who lack passion in carrying out their duties, which results in a lack of successful goals. MAN Unggul Tapaktuan has 28 teachers who have competence in carrying out their duties. To carry out effective tasks is certainly influenced by various factors, both factors that come from within (intrinsic) and that come from the environment (extrinsic). Each teacher has special characteristics, which are different from each other. This requires special attention and service from the leader, so that they can use the time to improve their performance. To improve employee performance, efforts are needed to arouse employee motivation and other factors that influence it.

\subsection{Leadership}

\section{Literature Review}

In English the word leadership is a leader that means "leader, talented leader, figure, then gets a suffix into leadership which means leadership, leadership".

Etymologically, leadership comes from the basic words of the leader. In English, leadership means leadership, from the root leader means the leader and the root word to lead which contains several meanings that are closely related such as: moving earlier, walking at the beginning, taking the first step, doing the first, pioneering, directing the mind - opinions of others, guiding, guiding, and moving others through their influence. In English, leadership is called leadership, whereas in Arabic it is called imamah and khiläfah.

In terms of terminology, there are several notions of leadership according to experts, as follows:

Koontz, O'Donnel and Weihrich, as mentioned by Wahjosumidjo said that what is meant by leadership in general is influence, art, or process influencing other people, so they willingly strive towards achieving organizational goals.

\subsection{Principal Leadership}

Internally, the school has a set of school principals / madrasah, teachers, students, curriculum, facilities and infrastructure. In this case, the principal holds the highest leadership in the school so that it can affect the performance and motivation of teachers, students and others. The principal or head of madrasah is one of the school / madrasah personnel who guides and has responsibilities with other members to achieve goals. The head of the madrasa is a teacher who has additional duties to foster and lead members to achieve goals. ${ }^{1}$

According to the Decree of the Minister of Education and Culture No. 0296 In 1996, School Principals were teachers who had additional duties to lead the implementation of education and efforts to improve the quality of school education. According to this provision the tenure is 4 (four) years which can be extended by one term of service. ${ }^{2}$

School leadership is the process of guiding and raising the talents and energy of teachers, students and parents to achieve the desired educational goals.

\subsection{Principal's Democratic Leadership Style}

The principal's leadership process is related to the leadership style he uses. Every leader in carrying out his leadership has a way and style. The leader has his own characteristics, habits, temperament, character and personality, so that his behavior and style distinguish him

\footnotetext{
${ }^{1}$ Helmawati, Meningkatkan Kinerja Kepala Sekolah... page. 17.

${ }^{2}$ Daryanto, Administrasi... page. 111.
} 
from others. His lifestyle will definitely color his behavior and type of leadership. There are leaders who are harsh and repressive, not persuasive, so that subordinates work with a sense of fear, there are also leaders who are gentle and usually favored by subordinates.

Hersey and Blancard explained: "The style of leader is a consistent behavior that is used when they are working with and through people as perceived by those people. This means that leadership style is a pattern of roles that leaders consistently use when they work with and through others as perceived by those people. The same opinion was also expressed by Thoha, that leadership style is a norm of behavior used by someone when the person tries to influence the behavior of others as he sees. So, to achieve a goal, it is necessary to have a leader or headmaster who has its own leadership style, so as to be able to influence the behavior of the teachers and can achieve the goals agreed upon.

The method or technique of carrying out a leadership is called the type or style of leadership. Daryanto formulates various leadership styles, namely democratic leadership style, authoritarian leadership style and free leadership style (laissez faire). One effective leadership style of principals includes having a democratic, straightforward, and open leadership style. Democratic leadership is implementing its leadership democratically. Leaders carry out their duties in such a way that a joint decision from all group members. Each member has the freedom to express his opinion. The leader's task is to guide and coordinate the decision-making process. In the way of democratic leadership there appears to be a tendency for mutual cooperation among group members. This leadership is considered the best, because it creates the highest working atmosphere and group productivity. In this democratic group there is excitement, they continue to work happily, there are or no leaders beside them. . ${ }^{3}$

Democratic leadership places humans as the main and most important factor in each group/organization. Democratic leadership in making decisions is very important for deliberation, which is realized at every level and within each unit.

\subsection{Indicators of Teacher's Work Motivation}

People work for different reasons so many theories that express opinions are different about motivation. School principals or principals as managers and motivators in organizations need to increase understanding of how individuals behave. The Work Motivation Indicators :

Internal motivation, the indicator:

- Responsibility for work;

- Have an interest in work;

- Satisfaction at work;

- There are needs that must be met;

- Enthusiasm at work.

Whereas external motivation, the indicator:

1. Get praise or attention from others;

2. Want to get money / incentives / rewards;

3. The desire to get an award or achievement;

4. Encouragement from superiors;

5. Interpersonal relationships;

6. Working conditions.

\footnotetext{
${ }^{3}$ Dita Amanah and others, Pengantar Manajemen, ...page. 203.
} 


\section{Methodology}

The approach in this study is a quantitative approach is one of the efforts of scientific search (scientific inquiry) which is based on logical positivism philosophy about logic, truth, laws, and predictions (Watson in Danim).

The term positivistic research is closely related and is synonymous with quantitative research. Research that adopts a positivistic view is based on assumptions that the main thing in the social environment is a reality that is free or independent and relatively constant about changes in time and background. Researchers who follow this positivistic flow develop knowledge through numerical data collection based on observable actions or behaviors from samples and then process the data with numerical analysis.

Method is a method used to research something so that conclusions can be taken. The method used in research is quantitative methods. Quantitative research is research that intends to understand a phenomenon about what is observed by researchers. Quantitative research is a method for testing certain theories by examining relationships between variables.

Quantitative research methods can be interpreted as research methods that are based on the philosophy of positivism, used to examine certain populations or samples, sampling techniques are generally done randomly, data collection uses research instruments, quantitative / statistical data analysis with the aim of testing hypotheses that has been established.

The study was conducted at State of Unggul Tapaktuan Madrasah Aliyah (MAN), located on Jl. T.Ben Mahmud Km.4, Air berudang village, Tapaktuan Subdistrict, South Aceh District with Madrasah statistics number 1311110110001. This Madrasah is the only State Islamic Senior High School in Tapaktuan sub-district, which has a strategic place to learn teaching because of its safe place, comfortable and clean environment and occupies a position that is easily accessible by public transportation.

\section{Results And Discussion}

\subsection{General description of State Madrasah Aliyah Unggul (MAN) Tapaktuan}

a. Profile of State Madrasah Aliyah Unggul (MAN) Tapaktuan, Unggul Tapaktuan Madrasah Aliyah Negeri (MAN) is located in the village of Air Berudang and is the only State Aliyah Madrasah in Tapaktuan District, which has a strategic place for teaching and learning because it occupies a strategic, convenient and easily accessible position by public transportation.

The state of the school of Superior Man of Tapaktuan can be seen in the following table:

Table 4.1: School Identity of Superior Man of Tapaktuan

\begin{tabular}{|l|c|l|}
\hline \multicolumn{3}{|c|}{ Identity of School } \\
\hline School & $:$ & MAN Unggul Tapaktuan \\
Address & $:$ & Air Berudang, Tapaktuan district. \\
Number and Establishment decree & $:$ & 64 Tahun 1990 \\
Calculated Start Date & $:$ & 25 April 1990 \\
Madrasah Statistics Number & $:$ & 1311110110001 \\
Address of Madrasah / Tel. Postal code & $:$ & Jl. T.Ben Mahmud Km.4 / 321953/23751
\end{tabular}




\begin{tabular}{|l|c|l|} 
Province & $:$ & Aceh \\
Regency / City & $:$ & Aceh Selatan \\
Sub-district & $:$ & Tapaktuan \\
Ownership/ Rent & $:$ & Ownership \\
Permanent . Semi Permanent & $:$ & Permanent \\
Amount of Space / Local Learning & $:$ & 12 rooms \\
\hline
\end{tabular}

Source: 2015 Tapaktuan Superior MAN Documentation Data

MAN Superior Tapaktuan already has five leadership. Of the five leadership, can be seen Mr. Drs. Nasrijal who has a longer leadership than others, so that he can achieve various achievements, especially the achievements of Tapaktuan Superior MAN students. However, it does not rule out the possibility that Mr Misbah, S.Ag can bring the Superior Man of Tapaktuan towards a higher quality.

b. Total of Teachers and Employees

Data of teachers and employees of MAN Unggul Tapaktuan (attached). The number of Teachers / Employees and Employees in MAN Unggul tapaktuan is 39 people, consisting of 21 permanent teachers, 7 permanent teachers, 5 permanent TU employees, 4 non-permanent TU employees and 2 temporary messengers. For more details, see the following table:

Table 4.2: The Total of teachers and employees.

\begin{tabular}{|l|l|l|l|}
\hline Personnel Information & Male & female & Total \\
\hline Regular Teacher & 8 & 13 & 21 \\
Non-Regular Teacher & 2 & 5 & 7 \\
Jobholder of administration & 3 & 2 & 5 \\
Non-Jobholder of administration & 2 & 2 & 4 \\
Regular Cleaning Service & - & - & - \\
Non- Regular Service & 2 & - & 2 \\
\hline Total & 17 & 22 & 39 \\
\hline
\end{tabular}

Source: 2015 Tapaktuan Superior MAN Documentation Data

Based on Table 4.2, it is known that the environmental conditions of MAN Superior Tapaktuan have permanent teachers and several non-permanent teachers for each field of study. This can support the Teaching and Learning process (PBM) in their respective fields of study with the appropriate teaching schedule as determined. Likewise with TU employees who are very helpful in terms of school administration.

c. The number of students

In its development MAN Superior Tapaktuan has 369 students, consisting of 97 students from class X, 147 students from class XI and 125 students from class XII. For more details, see the following table: 
Table 4.3: Number of students by class and gender

\begin{tabular}{|l|l|l|l|}
\hline \multirow{2}{*}{ Grade } & \multicolumn{3}{|c|}{ Total of Students } \\
\cline { 2 - 4 } & Male & Female & Total \\
\hline X-IPA $^{1}$ & 7 & 20 & 27 \\
X-IPA $^{2}$ & 12 & 14 & 26 \\
X-IPS $^{1}$ & 10 & 12 & 22 \\
X-IPS $^{2}$ & 13 & 9 & 22 \\
\hline Total & 42 & 55 & 97 \\
\hline XI-IPA $^{1}$ & 10 & 28 & 38 \\
XI-IPA $^{2}$ & 16 & 22 & 38 \\
XI-IPS $^{1}$ & 16 & 20 & 36 \\
XI-IPS $^{2}$ & 16 & 19 & 35 \\
\hline Total & 58 & 89 & 147 \\
\hline XII-IPA & 6 & 24 & 30 \\
XII-IPA $^{2}$ & 6 & 25 & 31 \\
XII-IPS $^{1}$ & 18 & 16 & 34 \\
XII-IPS $^{2}$ & 20 & 10 & 30 \\
\hline Total & 50 & 75 & 125 \\
\hline All Total & 150 & 219 & 369 \\
\hline
\end{tabular}

Source: 2015 Tapaktuan Superior MAN Documentation Data

\subsection{General Description of Characteristics of Respondents}

Characteristics of respondents in this study published gender, age, last education, position, length of time being a teacher, rank / class. Based on the results of the following data processing, a description of the respondents will be described based on:

a. Characteristics of respondents by sex

Based on the sex of the respondents the study understood 225 can be understood as follows:

Table 4.4 Characteristics of Respondents by Gender

\begin{tabular}{|c|l|l|l|}
\hline No & Sex & Frequency & Percentage \\
\hline 1 & Male & 10 & 35,7 \\
2 & Female & 18 & 64,3 \\
\hline Total & 28 & 100.0 \\
\hline
\end{tabular}

Source: Primary data processed, 2015

b. Characteristics of respondents based on age

Based on the age of the sex of the respondents, the total number of 28 respondents can be described as follows:

Table 4.5 Characteristics of Respondents by Age

\begin{tabular}{|c|l|l|l|}
\hline No & Age & Frequency & Percentage \\
\hline 1 & $<25$ years old & 1 & 3,6 \\
2 & $25-35$ years old & 10 & 35,7 \\
3 & $35-45$ years old & 7 & 25,0 \\
4 & $>45$ years old & 10 & 35,7 \\
\hline \multicolumn{2}{|l|}{ Total } & 28 & 100,0 \\
\hline
\end{tabular}

Source: Primary data processed, 2015 
Based on the age of the respondents from the above Table it can be explained that as many as 1 teacher respondent or $3.6 \%$ aged $<25$ years, respondents aged between 25-35 years were 10 teachers or $35.7 \%$ of the total respondents, respondents aged between 35 - 45 years as many as 7 teachers or $25.0 \%$ and 10 teachers or $35.7 \%$ aged $>45$ years. Thus the numbers of teachers who are respondents who are more dominant in this study based on age are teachers aged 25-35 years and teachers aged> 45 years.

c. Characteristics of respondents based on recent education

Based on the latest education the research respondents, which amounted to 28 teachers, can be described as follows:

Table 4.6 Characteristics of Respondents Based on Latest Education

\begin{tabular}{|l|l|l|l|}
\hline No. & Education & Frequency & Persentage \\
\hline 1 & Senior High School & 0 & 0 \\
2 & Associate Degree & 0 & 0 \\
3 & Bachelor Degree & 28 & 100,0 \\
4 & Master Degree/ Doctoral & 0 & 0 \\
\hline & Degree & & 100,0 \\
\hline
\end{tabular}

Source: Primary data processed, 2015

Characteristics of respondents based on the latest education can be explained from the table above, that all respondents were 28 respondents or $100.0 \%$ had the last education S1.

d. Characteristics of respondents based on position

Based on the research respondent's position, 28 teachers can be described as follows:

Table 4.7 Characteristics of Respondents by Position

\begin{tabular}{|c|l|c|c|}
\hline No. & Position & Frequency & Persentage \\
\hline 1 & Devoted & 1 & 3,6 \\
2 & Contract & 0 & 0 \\
3 & Honor & 6 & 21,4 \\
4 & Civil servants & 21 & 75,0 \\
\hline Total & 28 & 100,0 \\
\hline
\end{tabular}

Source: Primary data processed, 2015

The characteristics of the next respondent are based on position, it can be explained that as many as 21 teacher respondents or $75.0 \%$ have positions as civil servants, as many as 6 teacher respondents or $21.4 \%$ have positions as honor teachers, and 1 respondent or $3.6 \%$ have positions as devoted. Thus the numbers of teachers who become respondents who are more dominant in this study based on position are teachers who have the position as teachers of Civil Servants.

e. Characteristics of respondents based on the length of time being a teacher Based on how long the respondents have become teachers, 28 can be described as follows: 
Table 4.8 Characteristics of Respondents Based on the length of time being a teacher

\begin{tabular}{|c|l|c|c|}
\hline No. & Range time as Teacher & Frequency & Persentage \\
\hline 1 & $1-7$ years & 8 & 28,6 \\
2 & $8-14$ years & 9 & 32,1 \\
3 & -22years & 7 & 25,0 \\
4 & $>23$ years & 4 & 14,3 \\
\hline Total & 28 & 100,0 \\
\hline
\end{tabular}

Source: Primary data processed, 2015

Viewed from the length of time the respondents have become teachers, it can be explained that as many as 9 teacher respondents or $32.1 \%$ have been $8-14$ years as teachers, as many as 8 teacher respondents or $28.6 \%$ have $1-7$ years become teachers, as many as 7 teachers or $25.0 \%$ have been teachers for 15-22 years, as many as 4 teacher respondents or $14.3 \%$ have $>23$ years become a teacher,

f. Characteristics of respondents based on rank / class

Based on the rank / class of the research respondents which number 28 can be described as follows:

Table 4.9 Characteristics of Respondents by rank / class

\begin{tabular}{|c|l|c|c|}
\hline No. & Level/grade & Frequency & Percentage \\
\hline 1 & Not yet & 7 & 25,0 \\
2 & II/a-II/c & 1 & 3,6 \\
3 & III/a-III/d & 10 & 35,7 \\
4 & IV/a - Up to & 10 & 35,7 \\
\hline \multicolumn{2}{|c|}{ Total } & 28 & 100,0 \\
\hline
\end{tabular}

Source: Primary data processed, 2015

The last characteristic of the respondents is based on position / group, it can be explained that 10 teacher respondents or $35.7 \%$ have positions III / a-III / d and 10 teacher respondents or $35.7 \%$ have positions IV / a and above, as many as 7 teacher respondents or $25.0 \%$ do not have a position, and 1 teacher respondent has a position II / a.

\subsection{Categories (index number analysis)}

a. Category (index number analysis) level of Principal Style of Leadership Democracy in Superior School MAN Tapaktuan.

The Level of Leadership Style of the Leadership of the State of Tapaktuan MAN Unggul is grouped into three categories, namely high, medium and low. The results of the grouping level of the Leadership Style of the Principal of the Superior School of MAN Tapaktuan using the SPSS version 21 program can be seen as follows:

Table 4.10 Results of categories (index number analysis) democratic leadership style

\begin{tabular}{|c|l|c|c|}
\hline No. & Categories & Frequency & Percentage \\
\hline 1 & Good & 6 & 21,4 \\
2 & Enough & 18 & 64,3 \\
3 & Less & 4 & 14,3 \\
\hline \multicolumn{2}{|c|}{ Total } & 28 & 100 \\
\hline
\end{tabular}

Source: Primary data processed, 2015

This category can also be seen in the graph below: 
Graph 4.1: Histogram of the style of democratic leadership of the principal

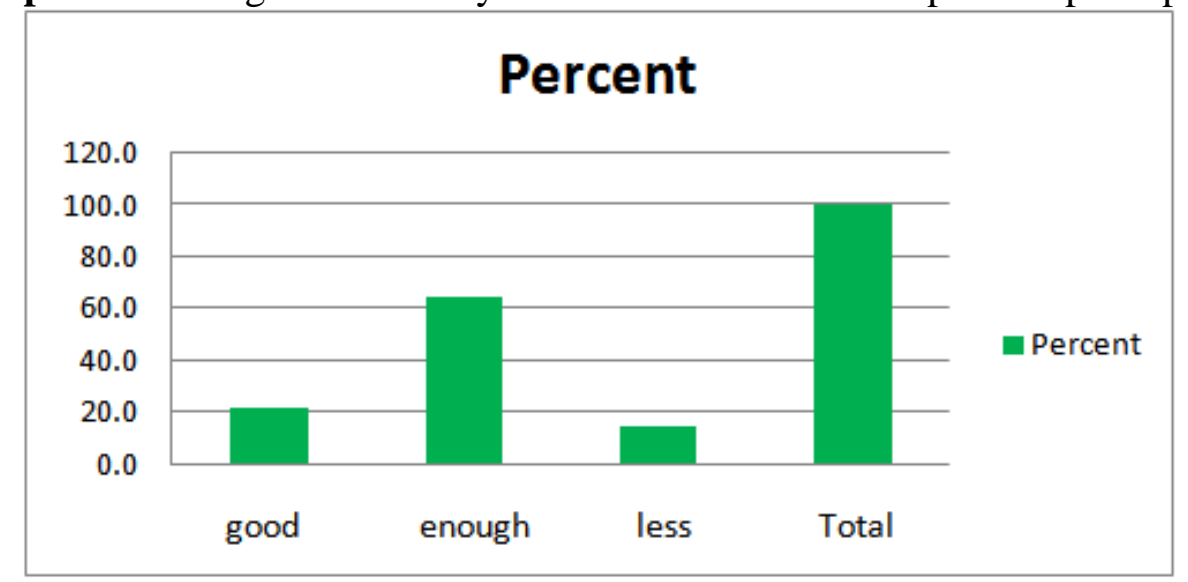

Source: Primary data processed, 2015

b. Category (index number analysis) level of Teacher Work Motivation

The level of motivation of teacher work in th state of MAN Unggul of Tapaktuan is grouped into three categories, namely good, sufficient, less. The results of grouping the level of motivation of teacher work in the Superior MAN Tapaktuan using the SPSS version 21 program can be seen as follows:

Table 4.11 Results of categories (index number analysis) work motivation

\begin{tabular}{|c|l|c|c|}
\hline No. & Category & Frequency & Percent \\
\hline 1 & High & 5 & 17,9 \\
2 & Medium & 20 & 71,4 \\
3 & Low & 3 & 10,7 \\
\hline \multicolumn{2}{|c|}{ Total } & 28 & 100 \\
\hline
\end{tabular}

Source: Primary data processed, 2015

From the above table it is known that more than half of the respondents $(71.4 \%)$ have a moderate level of work motivation, (17.9\%) have a high category of work motivation and the rest $(10.7 \%)$ have a low category of work motivation. This category can also be seen in the graph below:

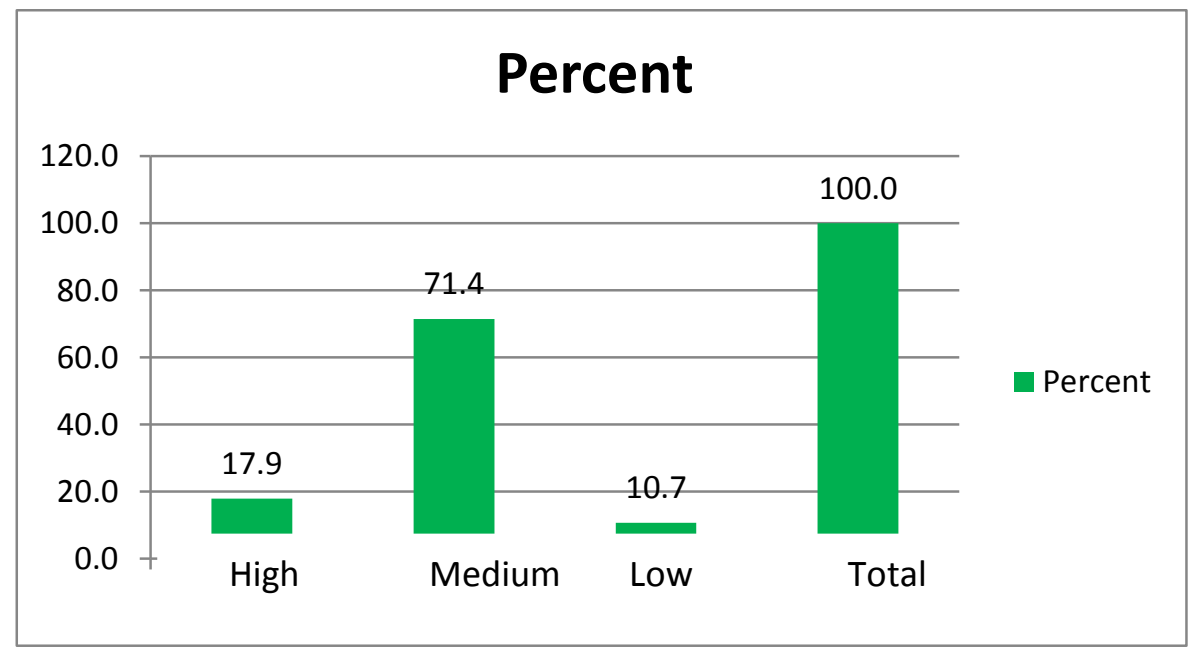




\section{4 Test of Prerequisites for Analysis or Test of Classical Assumptions}

The requirements analysis test was conducted with the aim to find out whether the data collected fulfilled the requirements to be analyzed by the techniques planned by the researcher. The form of distribution of all variables from research subjects must be normally distributed. Then, the requirements analysis of basic assumptions is such as normality and linearity, and heterocedasticity. The assumption that the population is normally distributed needs to be checked, so that the next steps can be accounted for.

a. Normality Test with Kolmogorov-Smirnov

The normality test is carried out to determine whether the data that has been collected is normally distributed or not. This test is carried out in order to determine the statistical test to be used. The researcher used the help of SPSS version 21 by looking at the values at Kolmogorov-Smirnov.

Table 4.12: Normality test results

\begin{tabular}{|l|l|l|l|}
\hline Variabel & $\begin{array}{l}\text { Kolmogorov- } \\
\text { Smirnov }\end{array}$ & Sig. & Keterangan \\
\hline $\begin{array}{l}\text { Gaya kepemimpinan } \\
\text { Demokrasi }\end{array}$ & 0,747 & 0,633 & Normal \\
\hline Motivasi Kerja Guru & 0,783 & 0,572 & Normal \\
\hline
\end{tabular}

Source: Primary data processed, 2015

Based on the results of the basic analysis of decision making is based on probability, namely: If the probability value is $>0.05$ then the population is normally distributed If the probability value is $<0.05$, the population is not normally distributed. $\mathrm{X}$ (Principal's Democratic Leadership Style) which is 0.633 which means $>0.05$ then the population is normally distributed, while Y (Teacher's Work Motivation) has a sig value. 0.572 is which means $>0.05$, the population is normally distributed. (attached)

Figure 4.1: Normality test results

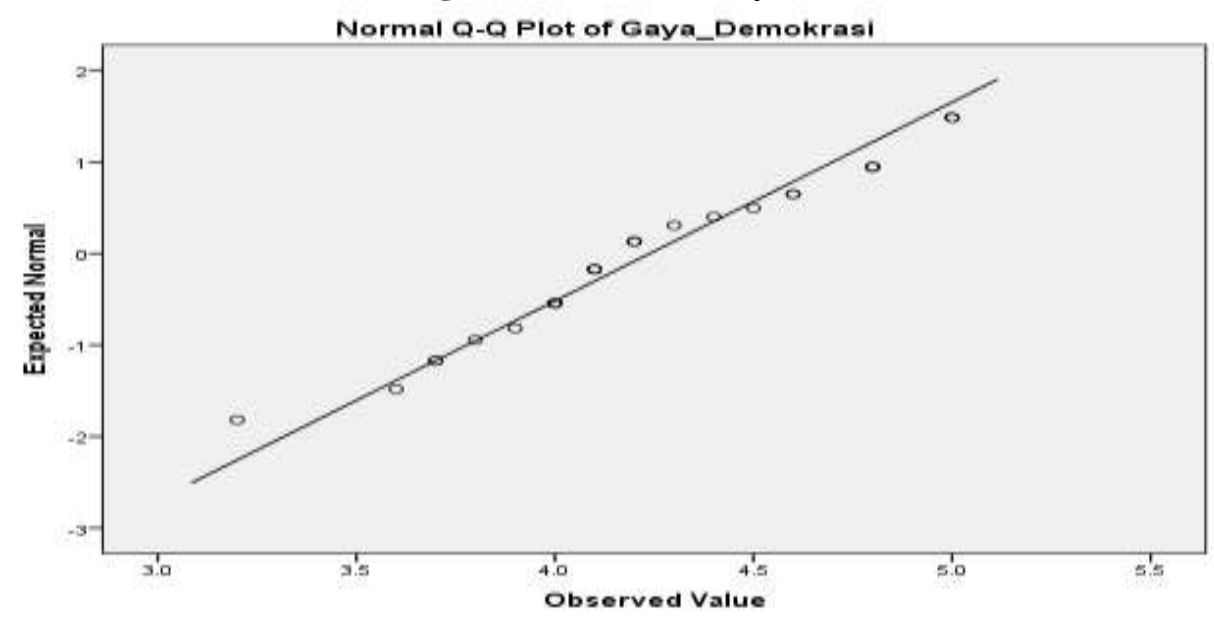

b. Linearity Test

The purpose of the linearity test is to find the regression line equation variable $\mathrm{X}$ for the dependent variable $\mathrm{Y}$. The linearity test is intended to find out whether the equation model that we have is suitable or not. If it is not linear, the regression analysis cannot continue. 
Table 4.13: Linearity Test Results

\begin{tabular}{|c|c|c|c|c|c|c|}
\hline \multicolumn{7}{|c|}{ ANOVA Table } \\
\hline & & $\begin{array}{l}\text { Sum of } \\
\text { Squares }\end{array}$ & $\overline{\mathrm{Df}}$ & $\begin{array}{l}\text { Mean } \\
\text { Square }\end{array}$ & $\mathrm{F}$ & Sig. \\
\hline Gaya_Demokrasi & (Combined) & 3.229 & 18 & .179 & .646 & 794 \\
\hline * Motivasi_Kerja_Between Groups & Linearity & 1.347 & 1 & 1.347 & 4.855 & .055 \\
\hline Guru & $\begin{array}{l}\text { Deviation } \\
\text { from } \\
\text { Linearity }\end{array}$ & 1.881 & 17 & .111 & .399 & 951 \\
\hline Within Groups & & 2.498 & 9 & .278 & & \\
\hline Total & & 5.727 & 27 & & & \\
\hline
\end{tabular}

Source: Primary data processed, 2015

Based on the table above it can be seen the results of linearity test using the Deviation from Linearity. That two variables are said to have a linear relationship, if the significance value is above $0.05^{4}$. This is also in line with the opinion of Burhan Nurgiyantoro et al, stating that if the value of $f_{\text {count }}>f_{\text {table }}$ at a significance level of $5 \%$ then it is stated that the data regression line is linear. If the value of $\mathrm{F}$ count $>\mathrm{F}$ table, then it is stated that the data regression line is not linear.

The linearity test results can be seen in the ANOVA Output table, in column F, Deviation from Linearity that is $f_{\text {count }} 0.399<f_{\text {table }} 4.23$ with significance 0.951 (above 0.05), thus $\operatorname{sig}>\alpha(0.951>0.05)$ then It can be stated that the relationship between variables of democratic leadership style and work motivation is linear and allows to use regression analysis.

c. Heterocedasticity

The results of the heterocedasticity test, as seen in the picture below:

Figure 4.2: Heterocedasticity test results

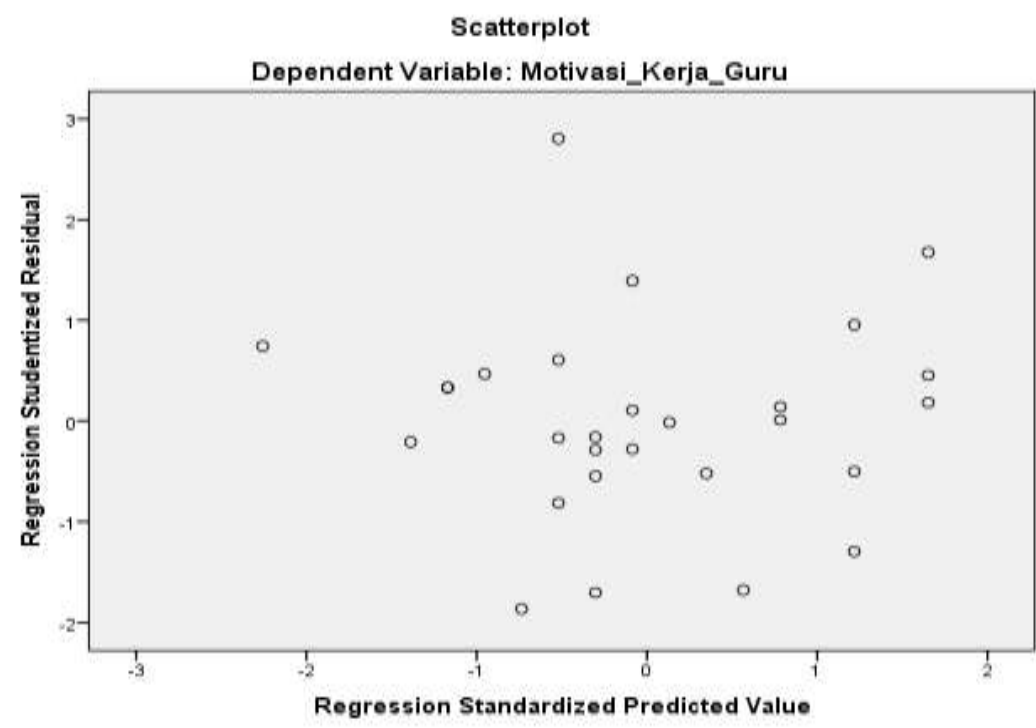

Source: Primary data processed, 2015

\footnotetext{
${ }^{4}$ Juliansyah Noor, Metodologi Penelitian, (Jakarta:Kencana,2011),on page.185
} 
The picture above shows dots spreading randomly, does not form a clear / regular pattern, and spreads both above and below the number 0 on the $\mathrm{Y}$ axis. Thus there is no heterocedasticity in the regression model.

\subsection{Hypothesis Testing}

The research hypothesis is a hypothesis that contains a statement about the relationship or influence, either positively or negatively between two variables or more in accordance with the theory. This study aims to determine the effect of the principal's democratic leadership style on teacher work motivation in the Tapaktuan Superior State Madrasah Aliyah. In expressing the problem and testing the existing hypothesis, a statistical analysis of the data obtained using SPSS version 21 was carried out. Data analysis performed in testing the hypothesis in this study was using simple regression analysis, correlation and coefficient of determination (R2). ${ }^{5}$

a. Simple Regression Analysis

Regression is used to determine the pattern of the dependent variable which can be predicted through independent variables. Regression analysis used in this study is simple regression analysis because the independent variable $(\mathrm{X})$ is examined to predict the value of the dependent variable $(\mathrm{Y})$, only one independent variable $(\mathrm{X})$.

Table 4.14: Simple regression test results

\begin{tabular}{|c|c|c|c|c|c|c|}
\hline \multicolumn{7}{|c|}{ ANOVA $^{\mathrm{a}}$} \\
\hline \multirow{2}{|c|}{ Model } & Sum of Squares & Df & Mean Square & F & Sig. \\
\hline & Regression & 1.347 & 1 & 1.347 & 8.000 & $009^{\mathrm{b}}$ \\
\cline { 2 - 7 } & Residual & 4.379 & 26 & 168 & & \\
\cline { 2 - 7 } & Total & 5.727 & 27 & & & \\
\hline \multicolumn{7}{|c|}{ a. Dependent Variable: style_Democration } \\
\hline \multicolumn{7}{|c|}{ Source: Primary Data processed, 2015 }
\end{tabular}

Based on the data obtained above, hypothesis testing can be seen in the ANOVA output column Sig. or compare with t table. So from the regression results in the table above, it can be explained that the Sig. $0.009<0.05$, then Ho is rejected, which means that there is a significant influence between the principal's democratic leadership style on teacher work motivation in the Tapaktuan Superior State Islamic Senior High School. And the results of a simple regression test can also be seen by comparing $t$ count with t table as seen in the table below:

Table 4.15: Simple regression test results by looking at table

\begin{tabular}{|l|c|c|c|c|c|}
\hline \multicolumn{7}{|c|}{ Coefficients $^{\mathrm{a}}$} \\
\hline \multirow{2}{*}{ Model } & \multicolumn{2}{|c|}{$\begin{array}{c}\text { Unstandardized } \\
\text { Coefficients }\end{array}$} & $\begin{array}{l}\text { Standardized } \\
\text { Coefficients }\end{array}$ & $\mathrm{T}$ & Sig. \\
\cline { 2 - 4 } & $\mathrm{B}$ & Std. Error & Beta & \\
\hline
\end{tabular}

\footnotetext{
${ }^{5}$ Juliansyah Noor, Metodologi Penelitian,( Jakarta : Kencana, 2011), on page. 183.
} 


\begin{tabular}{|c|c|c|c|c|c|c|}
\hline 1 & (Constant) & 2.043 & .706 & & 2.895 & .008 \\
\cline { 3 - 7 } & Gaya_Demokrasi & .468 & .165 & .485 & 2.828 & .009 \\
& & & & & & \\
\hline \multicolumn{6}{|c|}{ a. Dependent Variable: Motivasi_Kerja_Guru }
\end{tabular}

Source: Primary Data processed, 2015

The table above shows that the value of democratic style $(\mathrm{X})$ is 0.468 while constant or teacher work motivation (Y) is 2.043 . So for 0.468 the democratic leadership style of the principal towards the teacher's work motivation, the increasing value of the democratic style will increase the motivation of the teacher's work. Or with the equation: ${ }^{6}$

$\hat{\mathrm{Y}}=\mathrm{a}+\mathrm{bX}$

$\hat{\mathrm{Y}}=2.043+0.468 \mathrm{X}$

Whereas for $t_{\text {count }}$ is 2.828 and $t_{\text {table }}$ is 2.055 , the basis for decision making is if the $t_{\text {count }}>t_{\text {table }}$ and then, the influence of the democratic leadership style is on the motivation of the work of the teacher. So, in this study prove that $t_{\text {count }}>t_{\text {table }}$ $(2,828>2,055)$. Based on the values that have been obtained, it can be interpreted that the democratic leadership style of the principal is one of the supporting factors of teacher work motivation with a probability of 0.05 .

b. Correlation Analysis

Correlation test is used to find the relationship of independent variables with dependent variables. This correlation analysis is further processed using the SPSS version 21 program.

The results obtained the correlation of count is 1.592 . If $t_{\text {count }}>t_{\text {total }}$ then $H_{0}$ is rejected and $\mathrm{Ha}$ is accepted, then 1.592> 1.314 so there is a relationship between the democratic leadership style of the principal towards teacher work motivation with a probability level of 0.20 .

Table 4.16: Correlation test results

\begin{tabular}{|c|c|c|c|c|}
\hline \multicolumn{5}{|c|}{ Correlations } \\
\hline & & & $\begin{array}{l}\text { Democratic } \\
\text { style }\end{array}$ & $\begin{array}{l}\text { Motivation - } \\
\text { Work }\end{array}$ \\
\hline \multirow{6}{*}{ Spearman's rho } & \multirow{3}{*}{ Democratic style } & $\begin{array}{l}\text { Correlation } \\
\text { Coefficient }\end{array}$ & 1.000 & $.507^{* *}$ \\
\hline & & Sig. (2-tailed) & & .006 \\
\hline & & $\mathrm{N}$ & 28 & 28 \\
\hline & \multirow{3}{*}{ Motivation -Work } & $\begin{array}{l}\text { Correlation } \\
\text { Coefficient }\end{array}$ & $.507^{* *}$ & 1.000 \\
\hline & & Sig. (2-tailed) & .006 & \\
\hline & & $\mathrm{N}$ & 28 & 28 \\
\hline
\end{tabular}

\footnotetext{
${ }^{6}$ Sudjana, Metoda Statistika, (Bandung: Tarsito, 2001), on page. 312
} 
Based on the results of the Spearman's rho test, the Sig. (2-tailed) or $p_{\text {value }} 0,006$ (because of $\left.p_{\text {value }}<0,05\right)$ then there is a significant correlation between the democratic leadership style of the principal towards teacher work motivation in the Tapaktuan Superior State Madrasah Aliyah. The Spearman correlation coefficient is 0.507 which means it shows that the direction of the positive correlation with a positive positive relationship.

c. Determination Coofesien Test (R2)

The coefficient of determination in linear regression is often interpreted as how much the ability of all independent variables to explain the variance of the dependent variable. In simple terms the coefficient of determination is calculated by squaring the Correlation Coefficient (R). Determination coefficient is used to determine the magnitude of the influence or contribution of the independent variable $(\mathrm{X})$ to the dependent variable (Y). Judging from the values in $\mathrm{R} \mathrm{Square.} \mathrm{The} \mathrm{R-Square} \mathrm{value} \mathrm{is} \mathrm{to}$ see how the variation in the value of the dependent variable is influenced by the independent variable. ${ }^{7}$

Table 4.17: Coefficient of determination test results

\begin{tabular}{|c|c|c|c|c|}
\hline \multicolumn{6}{|c|}{ Model Summary } \\
\hline Model & $\mathrm{R}$ & R Square & $\begin{array}{l}\text { Adjusted R Square } \\
\text { Std. Error of the } \\
\text { Estimate }\end{array}$ \\
\hline 1 & $.485^{\mathrm{a}}$ & .235 & .206 & .396 \\
\hline \multicolumn{6}{|c|}{ a. Predictors: (Constant), Democratic Style } \\
\hline
\end{tabular}

Source: Primary Data processed, 2015

From the results of the analysis of Table 4.16, the price of the correlation coefficient (r) is 0.485 and the coefficient of determination $(\mathrm{r} 2)$ is 0.235 . Then it can be interpreted that $23.5 \%$ of teacher work motivation is influenced by the principal's democratic leadership style positively. While $76.5 \%$ is determined by other variables not explained in this study. ${ }^{8}$

\section{Conclusion}

The results of the study show that there is an influence of the principal's democratic leadership style on teacher work motivation in the Tapaktuan Superior State Madrasah Aliyah. This statement is proven by the results of simple regression analysis processing with a value of $t_{\text {count }}>t_{\text {table }}(2,828>2,055)$ with a probability level of 0.05 . While the correlation analysis with the value of $t_{\text {count }}>t_{\text {table }}$ is $1.592>1.314$ with a probability of 0.20 . Based on the values that have been obtained, it can be interpreted that the democratic leadership style of the principal has a relationship and influence on the teacher's work motivation. While the regression analysis $\hat{Y}=2.043+0.468 \mathrm{X}$, that democratic leadership style of 0.468 affects teacher work motivation (2.043). If the value of democratic leadership style increases, it will also be followed by an increase in the value of teacher motivation.

\footnotetext{
${ }^{7}$ http://www.konsultanstatistik.com/2011/07/koefisien-determinasi-pada-regresi.html, acessed on March 1st, 2015 .

${ }^{8}$ Marihot Manullang dan Manuntun Pakpahan, Metodologi Penelitian, (Bandung : Cipustaka Media, 2014), on page 203.
} 
The effective contribution of the democratic leadership style of the principal obtained from the coefficient of determination ( $\mathrm{r} 2$ ) is 0.235 . Then it can be interpreted that the motivation of the teacher of superior manpower of Tapaktuan is $23.5 \%$ determined by the democratic leadership style of the principal. The results of this data analysis indicate that the democratic leadership style of the principal has a considerable value to be able to encourage the motivation of the teacher's work in the school. This can be seen from the behavior of the principal who always involves the teachers for deliberation in making decisions, willing to accept criticism and suggestions from the teacher, convey information, always establish harmonious communication with the teachers, and provide opportunities for teachers to be creative and innovate in activities learning. With this, the teachers are motivated to carry out learning routines so that they can improve student learning achievement.

\section{References}

Agustinus Hermino, Kepemimpinan Pendidikan Di Era Globalisasi, Yogyakarta: Pustaka Belajar, 2014.

Ary H.Gunawan, Sosiologi Pendidikan, Jakarta: Rineka Cipta, 2010.

Burhan Nurgiyantoro, at all, Statistik Terapan untuk Penelitian Ilmu-ilmu Sosial, Yogyakarta: Gajah Mada University Press, 2004.

Daryanto, Administrasi dan Manajemen Sekolah, Jakarta: Rineka Cipta, 2013. , Kepala Sekolah sebagai Pemimpin Pembelajaran, Yogyakarta: Gava Media, 2011.

Deni Koswara dan Halimah, 9 Kebiasaan Kepala Sekolah Efektif, Bandung: PT Pribumi Mekar, 2008.

Dita Amanah dkk, Pengantar Manajemen, Bandung: Citapustaka Media Perintis, 2013.

Enco Mulyasa, Manajemen \& Kepemimpinan Kepala Sekolah, Jakarta: Bumi Aksara, 2012 , Manajemen dan Kepemimpinan Kepala Sekolah, Jakarta: Bumi Aksara, 2011.

, Menjadi Kepala Sekolah Profesional, Bandung: PT Remaja Rosdakarya, 2007. , Manajemen Berbasis Sekolah, Bandung: PT.Remaja Rosdakarya, 2004.

Euis Karwati dan Doni Juni Priansa, Kinerja dan Profesionalisme Kepala Sekolah, Bandung: Alfabeta, 2013.

Endin Nasrudin, Psikologi Manajemen, Bandung: Pustaka Setia, 2010.

Husaini Usman, Manajemen Teori, Praktik, dan Riset Pendidikan, Jakarta: Bumi Aksara, 2011.

Helmawati, Meningkatkan Kinerja Kepala Sekolah/Madrasah Melalui Managerial Skills, Jakarta: Rineka Cipta, 2014.

Herabudin, Administrasi dan Supervisi Pendidikan, Bandung: Pustaka Setia, 2009.

Hamid Darmadi, Kemampuan Dasar Mengajar, Bandung: Alfabeta, 2012.

Hamzah B.Uno, Teori Motivasi dan Pengukurannya, Jakarta: Bumi Aksara, 2009.

Ihat Hatimah,dkk, Penelitian Pendidikan, Bandung: UPI PRESS, 2010.

Jamaluddin Idris, Manajerial dan Manajemen, Bandung: Citapustaka Media Perintis, 2013.

Juliansyah Noor, Metodologi Penelitian, Jakarta: Kencana, 2011.

John M. Echols dan Hasan Sadily, Kamus Inggris Indonesia, Jakarta: PT.Gramedia, 2006.

Kartini Kartono, Pemimpin dan Kepemimpinan, Jakarta: PT.Raja Grafindo Persada, 2004.

Miftah Thoha, Konsep Dasar dan Aplikasinya, Jakarta: Rajawali Pers, 2102.

Mulyono, Manajemen Administrasi \& Organisasi Pendidikan, Jogjakarta: Ar-Ruzz Media, 2012.

Margono, Metodologi Penelitian Pendidikan, Jakarta: Rineka Cipta, 2010.

Muwahid Shulhan, Model Kepemimpinan Kepala Madrasah dalam Meningkatkan Kinerja Guru, Yogyakarta: Teras, 2013.

Mesiono, Manajemen Organisasi, Bandung: Citapustaka Media Perintis, 2014. 
Budapest International Research and Critics in Linguistics and Education (BirLE) Journal Volume 2, No 1, February 2019, Page: 164-180 e-ISSN: 2655-1470 (Online), p-ISSN: 2655-2647 (Print) www.bircu-journal.com/index.php/birle emails: birle.journal@gmail.com birle.journal.aa@amail.com

Marihot Manullang dan Manuntun Pakpahan, Metodologi Penelitian, Bandung: Cipustaka Media, 2014.

Malayu S.P. Hasibuan, Manajemen Dasar, Pengertian dan Masalah, Jakarta: Bumi Aksara, 2011. Ngalim Purwanto, Administrasi dan Supervisi Pendidikan, Bandung: Remaja Rosdakarya, 2010. , Administrasi dan Supervisi Pendidikan, Bandung: PT. Remaja Rosda Karya, 2007. , Psikologi Pendidikan, Bandung: PT. Remaja Rosda Karya, 2006.

Punaji Setyosari, Metode Penelitian Pendidikan dan Pengembangan, Jakarta: Kencana, 2012.

Rohmat, Manajemen Kepemimpinan Kewirausahaan, Yogyakarta: Media Aksara, 2013.

Rusdi Pohan, Metodologi Penelitian, Banda Aceh: Ar-Rijal Institut, 2008.

Sudarman Danim, Kepemimpinan Pendidikan Kepemimpinan Jenius $(I Q+E Q)$, Etika, Perilaku Motivasional, dan Mitos, Bandung: Alfabeta, 2010.

Sutomo dkk, Manajemen Sekolah, Semarang: UNNES PRESS, 2011.

Saefullah, Manajemen Pendidikan Islam, Bandung: Pustaka Setia, 2012.

Sondang P. Siagian, Teori \& Praktek Kepemimpinan, Jakarta: PT. Rineka Cipta, 2003. , Teori Motivasi dan Aplikasinya, Jakarta: Rineka Cipta, 2012.

Sardiman, Interaksi \& Motivasi Belajar Mengajar, Jakarta: PT.Raja Grafindo Persada, 2012. Interaksi dan Motivasi Belajar, Yogyakarta: PT.Grafindo Persada,2003.

Sudarwan Danim, Motivasi Kepemimpinan dan Efektivitas Kelompok, Jakarta: Rineka Cipta, 2012.

Sugiyono, Metode Penelitian Pendidikan, Pendekatan Kuantitatif, Kualitatif, dan R\&D, Bandung: Alfabeta: 2013. , Metodologi Penelitian Kuantitatif, Bandung: Alfabeta, 2013.

Sukardi, Metodologi Penelitian Pendidikan, Jakarta: PT Bumi Aksara, 2010.

Trianto, Pengantar Penelitian Pendidikan bagi Pengembangan Profesi Pendidikan \& Tenaga Kependidikan, Jakarta: Kencana, 2011.

Tukiran Taniredja dan Hidayati Mustafidah, Penelitian Kuantitatif, Bandung: Alfabeta, 2012.

Winardi, Motivasi \& Pemotivasian dalam Manajemen, Jakarta: PT Raja Grafindo Persada, 2002.

Wasty Soemanto, Psikologi Pendidikan, Jakarta: Rineka Cipta, 2012.

Wibowo, Manajemen Kinerja, Jakarta: Rajawali Pers, 2011.

Wahjosumidjo, Kepemimpinan Kepala Sekolah, Tinjauan Teoritik dan Pemahamannya, Jakarta: Rajawali Pers, 2011.

W.J.S. Poerwadarminta, Kamus Umum Bahasa Indonesia, Jakarta: Balai Pustaka, 2007.

Adlan Adam, "Pengaruh Gaya Kepemimpinan Kepala Sekolah terhadap Kinerja Guru SD Negeri Kecamatan Gondokusuman Daerah Istimewa Yogyakarta", Skripsi (online:), accessed http://eprints.uny. ac.id/ 14246/1 /SKRIPSI.pdf, on September $29^{\text {th }}, 2016$.

Anita Juniarti, Pengaruh Gaya Kepemimpinan Kepala Sekolah terhadap Motivasi kerja Guru di MAN Malang II Batu, Skripsi (online) Fakultas Tarbiyah UIN Maulana Malik Ibrahim,2010),, diakses melalui situs https://www.scribd.com/doc/292089278/SkripsiPengaruh-Gaya-Kepemimpinan-Kepala-Sekolah-Terhadap-Motivasi-Kerja-Guru $\quad$ on September $29^{\text {th }}, 2016$.

Athika Candara Sasmy Argan, dalam penelitiannya yang berjudul, "Gaya Kepemimpinan Demokatis dalam Meningkatkan Kompetensi Profesional Guru PAI di SMA Negeri 1 Yogyakarta", Fakultas Ilmu Tarbiyah dan Keguruan, Jurusan Pendidikan Agama Islam, 2016, Skripsi (online) , diakses melalui http://digilib.uinsuka.ac.id/20169/1/11410183_BAB-I_IV-atau-V_DAFTAR-PUSTAKA.pdf.

Citra Pratiwi, "Pengaruh Tipe Kepemimpinan Demokratis Kepala Sekolah terhadap Kinerja Guru SD SE-Kecamatan Cangkringan Kabupaten Sleman”, Fakultas Ilmu Pendidikan Universitas 
Negeri Yogyakarta, 2014, Skripsi (online), accessed by http://eprints.uny.ac.id/14007/1/skripsi.pdf, on September $29^{\text {th }}, 2016$.

Eri Agustin, Pengaruh Motivasi Kerja terhadap Kinerja Guru Sekolah Dasar DABIN IV Kecamatan Kajen Kabupaten Pekalongan, Skripsi, Fakultas Ilmu Pendidikan Univertsitas Negeri Semarang, 2015.

http//file:///D:/statistik/Data\%20Penelitian\%20BkkbN/Uji\%20Reliabilitas\%20_\%20Konsultan\%2

0 SPSS. html, accessed on January 31 ${ }^{\text {st }}, 2017$.

http://makalah-ibnu.blogspot.co.id/2011/04/motivasi.html, Accessed on November $29^{\text {th }}, 2016$.

http://www.konsultanstatistik.com/2011/07/koefisien-determinasi-pada-regresi.html, accessed on March $1^{\text {st }}, 2019$.

Luthfi Nurul Hidayathi, dalam skripsinya yang berjudul "Pengaruh Gaya Kepemimpinan Kepala Sekolah dan Motivasi berprestasi terhadap Kinerja Guru SD Negeri Dabin I Kecamatan Cilacap Tengah Kabupaten Cilaca", Skripsi (online), Jurusan Pendidikan Guru Sekolah Dasar, Fakultas Ilmu Pendidikan, Universitas Negeri Semarang.2015, diakses melalui situs http://lib.unnes.ac.id/21711/1/1401411575-s.pdf, page 73

Norma Rosalia Dian Permatasari, dalam skripsinya yang berjudul "Hubungan Antara Gaya Kepemimpinan Demokratis dengan Motivasi Kerja Guru di SMK Negeri 1 Juwiring", Fakultas Psikologi Universitas Muhammadiyah Surakarta,2015, Naskah Publikasi (online:), accessed in http://eprints.ums.ac.id/37449/1/02.\%20Naskah\%20Publikasi.pdf., $\quad$ on September $29^{\text {th }}, 2016$.

Rudi Abu Azka, Accessed in http:// www.i bnukatsironline. com/ 2014/ 08/ tafsir-surat-albaqarah-ayat-30.html, on September $28^{\text {th }}, 2016$.

Sahid Raharjo, Uji Koofesien Korelasi Spearman dengan SPSS Lengkap, accessed in http:// www.konsistensi.com/2015/02/ujikoefisienkorelasispearmandengan .html, on December $1^{\text {st }}, 2016$.

, Tutorial SPSS, Uji Asumsi Dasar, 2014, Accessed in http:// www. spssindonesia . com /2014/ 01/uji-normalitas-kolmogorov-smirnov-spss.html, on December $1^{\text {st }}, 2016$

Syamsudin Serero, Pengertian Manajemen Kepemimpinan, 2014,Accessed in http:/ /shirotuna. blogspot.co.id/2014/06/kepemimpinan-manajemen-pendidikan-islam_17.html, Accessed on December $16^{\text {th }}, 2019$

Uji Reliabilitas, diakses melalui file:/// D:/ statistik/ Data\% 20 Penelitian \%20 BkkbN/ Uji\% 20 Reliabilitas \% 20 \%20Konsultan\%20SPSS.html, on December 1 $1^{\text {st }}, 2019$

Zuryati, dkk, "Gaya Kepemimpinan kepala Sekolah dalam Meningkatkan Kinerja Guru Pada SDN 7 Muara Dua Lhokseumawe", dalam Jurnal Administrasi Pendidikan,Jurnal (online) Vol.III, Prodi Magister Administrasi Pendidikan Unsyiah Banda Aceh, 2015, accessed in http://www.jurnal.unsyiah.ac.id/JAP/article/download/2540/2387, on September $29^{\text {th }}, 2019$ 